\title{
The Indonesian EFL Learners' Motivation in Reading
}

\author{
Hairus Salikin ${ }^{1}$, Saidna Zulfiqar Bin-Tahir ${ }^{2}$, Reni Kusumaningputri ${ }^{3} \&$ Dian Puji Yuliandari ${ }^{4}$ \\ ${ }^{1}$ English Department, Faculty of Humanities, Jember University, Indonesia \\ ${ }^{2}$ English Education Department, University of Iqra Buru, Indonesia \\ ${ }^{3}$ English Department, Faculty of Humanities, Jember University, Indonesia \\ ${ }^{4}$ English Department, Faculty of Humanities, Jember University, Indonesia \\ Correspondence: Saidna Zulfiqar Bin-Tahir, English Education Department, University of Iqra Buru, Indonesia. \\ E-mail: saidnazulfiqar@gmail.com
}

Received: March 19, 2017 Accepted: April 12, 2017 Online Published: April 14, 2017

doi: 10.5539/elt.v10n5p81 URL: http://doi.org/10.5539/elt.v10n5p81

\begin{abstract}
The motivation will drive the EFL learners to be successful in reading. This study examined the Indonesian EFL learners' motivation in reading activity based on Deci and Ryans' theory of motivation including intrinsic and extrinsic. This study employed mixed-method design. The data obtained by distributing questionnaire and arranging the group interviewed. The subject of the study involved 42 freshmen students of English department, the faculty of humanities at Jember University in the academic year 2015-2016. The results found that both intrinsic and extrinsic motivations have significant contribution in motivating the learners to read the English text. The intrinsic motivation played the important role in students' reading activities. Besides, the extrinsic motivation found the teacher's role as the learners' motivator in reading the English text through their method implemented in the reading class.
\end{abstract}

Keywords: motivation, intrinsic, extrinsic, reading skill

\section{Introduction}

Reading is the most convenient and cheapest way to obtain information. By reading, the reader can enrich their knowledge, broaden their views and make them understand many things about the world (Johnson \& Morrow, 1987). It is one of the important objectives of learning. For children and adults, reading skill will open up their views of the new world and a lot of opportunities. It allows them to acquire new knowledge, keep them update with the information and technology, enjoy literature, and carry out their daily work which is an indispensable part of modern life, such as reading the newspaper, registering the job, instructing manuals, and maps (Pang, 2003).

The most important activity in the formal language learning inside the classroom is reading. It is not only for the source of information and enjoyable activity but also as tools for consolidating and extending knowledge of the language. In the other words, the activity of reading can provide many benefits for students such as information, pleasure, and knowledge. In this way, the students not only read but they are also able to comprehend the written text of reading materials given from books, magazines, newspaper, and science and technology (Rivers, 1981).

Reading has played an important role in the language learning process, especially for the EFL (English as a Foreign Language) learners. This is the most important aspects for students to develop their L2 competence (Troike, 2006). It also becomes the primary channel and the main source for L2 input. In addition, by reading, learners can enrich their knowledge of the language in terms of grammar, discourse structure, and also vocabulary. Nowadays, reading is considered unpopular and undesirable activity for the students. Some researchers argued that students do not read their textbook even though they are aware of its usefulness (Kwedlju as cited in Masduqi, 2014). Some others stated that the lack of freshmen students' interest in reading classes because they are not familiar with the topic and the explanation of the text (Rukmini as cited in Masduqi, 2014).

Since reading is an important language skill in the language learning process, it is necessary to improve the L2 learners' reading activity. The motivation is a way that can help the learners to raise awareness and willingness to participate in reading class. Komiyama (2013) states that reading is positively related to motivation. It is due to motivation that can encourage learners to read and obtain their objectives in language learning. The motivation is 
the combination of efforts and one's desire to achieve the purposes of language learning (Mao, 2011).

In reality, most of the students especially the freshmen students of Jember University have low achievement in English reading. They considered that reading English text is difficult and boring activity. It makes them less motivated to learn English, especially in reading. It was supported by Bin-Tahir (2012) who argued that most of the students have low of vocabulary mastery which hindered them to read the English text. Tomlinson in Masuhara (2003) stated that in reading English text, many learners consider that they have to know all the words in the text in order to understand the text. It is in line to what stated by Deporter and Hernacki (1999) that reading is anxiety for students; even students are merely able to finish answering the questions in time, many students found it very difficult; they just often concern to the word by word, read a paragraph slowly until the last minutes of time given then they realize that they did nothing to answer the reading assignments and the comprehension questions completely. Bin-Tahir and Hanapi (2017) stated that the differences of spelling between L1 and target language affecting the low of students' motivation. It was also supported by Salikin and Bin-Tahir (2017) that the students felt boredom and unmotivated to comprehend the English texts. This is due to the misunderstanding of the English texts they read and confused to answer the questions of English texts.

Dhanapala (2008) studied "Motivation and L2 Reading Behaviors of University Students in Japan and Sri Lanka". She investigated the intrinsic and extrinsic motivations in L2 reading among 247 Japanese and Sri Lanka university students using the Motivation for Reading Questionnaire (MRQ). She also examined the interrelationship among items in the MRQ. This research finds that L2 reader has both intrinsic and extrinsic motivations simultaneously. Moreover, the results of the analysis suggest that the motivation in L2 reading can be observed by using intrinsic-extrinsic reading motivational proposed by Wang and Guthrie (2004).

Komiyama (2013) also studied "Factors underlying second language reading motivation of adult EAP students". In this article, she identifies reading motivation among 2.018 EAP's students (English for Academic Purpose) from 53 English language programs. This study involves three phases. Firstly, developing questionnaire proposed by Wang and Guthrie (2004) so that it can be reliably used by the researcher in measuring students' L2 reading motivation. Secondly, she used the revised questionnaire to identify the factor structure of L2 reading motivation. The last, she tries to examine the stability of the identified factors. From this study, she proposes the Motivation for Reading in English Questionnaire (MREQ) that is available to investigate L2 reading motivation. Besides, she also finds five factors that are best for interpreting the data, it includes one intrinsically-oriented factor (intrinsic motivation) and four extrinsically-oriented factors (drive to excel, academic compliance, test compliance, social sharing).

Based on the background, this study aimed to know the L2 learners' motivation in reading by adopting the motivation theory of Deci and Ryan (2000) consisted of intrinsic and extrinsic motivation. The study involved the freshmen students of English Department Faculty of Humanities, Jember University, Indonesia in the academic year 2015-2016. This study attempted to know the intrinsic motivations within the EFL students in reading the English text; to know the extrinsic motivations within the EFL students in reading, and to know the way of intrinsic and extrinsic motivations of EFL students in reading activity. This study hopefully gives some contributions to the teaching and learning reading activities that can be adapted and adopted by teachers and further researchers in the field of the study.

\section{Review of Literature}

Motivation is an emotional reaction in which the students get a benefit, reward, or the potential for a positive reward in a task. Corbin suggests that while the extrinsic and intrinsic factors that influence motivation varies, the following factors appear to influence the motivation in learning: relevance, control and choice, challenge, social chance to work with others, the alleged sense of success, need, novelty, cognitive dissonance or discrepant events (Corbin, 2008).

The motivation to learn increases when the students find relevance in the material or feel there was a need to know the specific content. The students find incentives in the lessons that they are connected with and apply to their own lives and experiences. Teenagers also respond well when they could exert some independence in the learning process. This is done by giving the students some control or input into their own education and offers the choices in terms of assignments, projects, and other outcome assessments (Kirby \& McDonald, 2009).

Motivation consists of intrinsic and extrinsic. The intrinsic motivation is including the engagement, curiosity, and the preference for the challenge. The extrinsic motivation involves the extrinsic drive to excel, extrinsic academic compliance, extrinsic test compliance, and extrinsic social sharing. The intrinsic motivation is defined as doing an activity because of the satisfaction to be gained by doing it. This kind of motivation also provides enjoyment and challenge for the people who do. It can be assumed that the reward obtained by performing the activity is innate the 
satisfaction of psychological needs. In other words, engaging in the activity itself is the reward for the person who motivated intrinsically. Intrinsic motivation is served by three constructs (Komiyama, 2013).

According to Komiyama (2013), engagement means the pleasure to be obtained by reading books, articles, or website written and published on the interesting topics. It can also be defined the level of engaging and involving in reading (Wang \& Guthrie, as cited in McGeown, 2013:3). Komiyama (2013) defines curiosity as a desire for someone to learn about a particularly interesting topic. The last factor in intrinsic motivation is the preference for the challenge. It is defined as a desire to work with or control complex reading materials (Wang \& Guthrie as cited in McGeown, 2013). Komiyama (2013) says that preference for the challenge is the satisfaction acquired by mastering or assimilating complex ideas in the text. Learners are motivated by this factor would be satisfied if they finish reading such a difficult material or text.

Deci \& Ryan (2000:60) define the extrinsic motivation as factors related to the objective of doing an activity is to get some separated results. It is also influenced by factors such as external rewards (e.g., recognition), internal feelings (e.g, guilt), and societal values (e.g., importance) that have been set for a goal activity (Deci \& Ryan, as cited in Komiyama, 2013). Komiyama split the extrinsic motivation into four factors which involve the extrinsic drive to excel, extrinsic academic compliance, extrinsic test compliance, and extrinsic social sharing.

The extrinsic and intrinsic motivation based on SDT as stated above is similar to the type of motivation based on SLA (Second Language Acquisition) by Gardner and Lambert, 1959 (as cited in Ahmadi, 2011). They divide motivation into Integrative and Instrumental motivation. These kinds of motivation are related to the individual needs for achievement or goals toward learning the second language. The type of motivation that is used in this study is intrinsic and extrinsic motivations based on Deci and Ryan. So, it can be said that this study is only focused on the social environment that has high possibility to influence human motivation to do an activity.

Intrinsic motivation refers to engage in an activity because it provides satisfaction, enjoyment and even interest or challenge to the activity itself. As stated by Deci and Ryan (2000), intrinsic motivation can trigger someone to do an activity because the activity is interesting. It means that someone who is intrinsically motivated tends to do an activity just for pleasure. Someone who is intrinsically motivated will definitely participate in an activity without any external and internal pressure or even when there is no reward behind (Deci \& Ryan 1985, as cited in Barkoukis et al., 2008). On the other hand, extrinsic motivation refers to the doing of an activity because of internal or even external pressure. For example, learners do something because they avoid of being punished by their teacher. In this case, it is shown that they do something just because of their fear instead of their satisfaction. Besides, being engaged in an activity in order to gain a reward is also considered as the extrinsic form of motivation. It can be concluded that extrinsic motivation will make someone behave not for its own sake but there are some environmental factors that affect someone in doing an activity. The theory above is used as the base theory of this study which it is connected to L2 reading activity. Then, the theory is used to describe the role of motivation in L2 reading activity, especially in intrinsic and extrinsic motivations. Intrinsic reading motivation refers to individual's enjoyment of reading something and also personal interest while extrinsic reading motivation is motivation caused by external demands in gaining good grades, obtaining recognition from others, or avoiding punishment.

\section{Method}

This study employed mixed-method design. Denscombe (2007) defines a mixed method strategy as one that uses both qualitative and quantitative method in research. The quantitative data is taken by distributing the questionnaire to the participants. Then, there is a follow-up interview to the informants which is interpreted as the qualitative data.

The subject of the study was all freshmen of English Department Faculty of Humanities, Jember University in the academic year 2015-2016. The total amount of the freshmen students were 101 students. This subject was selected based on reading 1 (one). There were four classes in Reading Class 01 for freshmen in which every class contains 25 students. Then the subjects were chosen from two reading classes taught by two different teachers. The total of the students in those classes were 42 students. The subject of the study has taken using the purposive sampling technique. Dornyei (2007) argues that the purposive sampling should have a plan that lines up with the purpose of the study. Besides, the purposive sampling was also based on the judgment of the researcher when selecting the units that are to be studied. The target of this study is to know the reading motivation of the freshmen students which is heterogeneous of the sample is really important so the sample can represent all freshmen students in English Department.

In analyzing the data, some steps were applied. First, the questionnaire is distributed to the participants. Second, the questionnaire is collected after the participants have finished answering the questionnaire. Subsequently, the 
quantitative data are processed. The questionnaire is counted and grouped based on the type of reading motivation; intrinsic and extrinsic motivation. Then, the questionnaire's results are provided in the form of percentages. Hereafter, it is examined based on how many percentages of each item are got. It shows whether the items of intrinsic and extrinsic motivations are taking roles in the learners' reading activity. Fourth, the interview questions are prepared based on the result of quantitative data. Fifth, the discussion is held and recorded. Sixth, the record of group discussion is transcribed. Seventh, the transcription is analyzed and compared with the quantitative data. It is aimed at knowing whether the qualitative supports the quantitative data.

\section{Results}

The data obtained from the questionnaire were taken by distributing MREQ (the Motivation for Reading in English Questionnaire) proposed by Komiyama (2013) into 42 freshmen. The result is presented in the percentage based on Likert Scale model ranging from "very different from me", presented by number "1", to "a lot of like me" that is presented by number " 4 ". The items in the table indicate the question statements of the MREQ.

Table 1. The result of questionnaire in intrinsic motivation: involvement

\begin{tabular}{lllll}
\hline Items & 1 & 2 & 3 & 4 \\
\hline 1.1 & 2.4 & 33.3 & 40.5 & 23.8 \\
1.2 & 2.4 & 9.5 & 42.9 & 45.2 \\
1.3 & 7.1 & 35.7 & 38.1 & 19.04 \\
1.4 & 4.8 & 42.9 & 30.95 & 21.4 \\
1.5 & 19.04 & 42.9 & 23.8 & 16.7 \\
\hline
\end{tabular}

Table 1 shows the involvement construct in the intrinsic motivation factor comprises of five question statements. The largest percentage was shown by the item number 1.2 in four-point Likert scale. $45.2 \%$ of the EFL students' answer that they are motivated in reading English text when they were reading their favorite topic.

Table 2. The result of questionnaire in intrinsic motivation: curiosity and preference for challenge

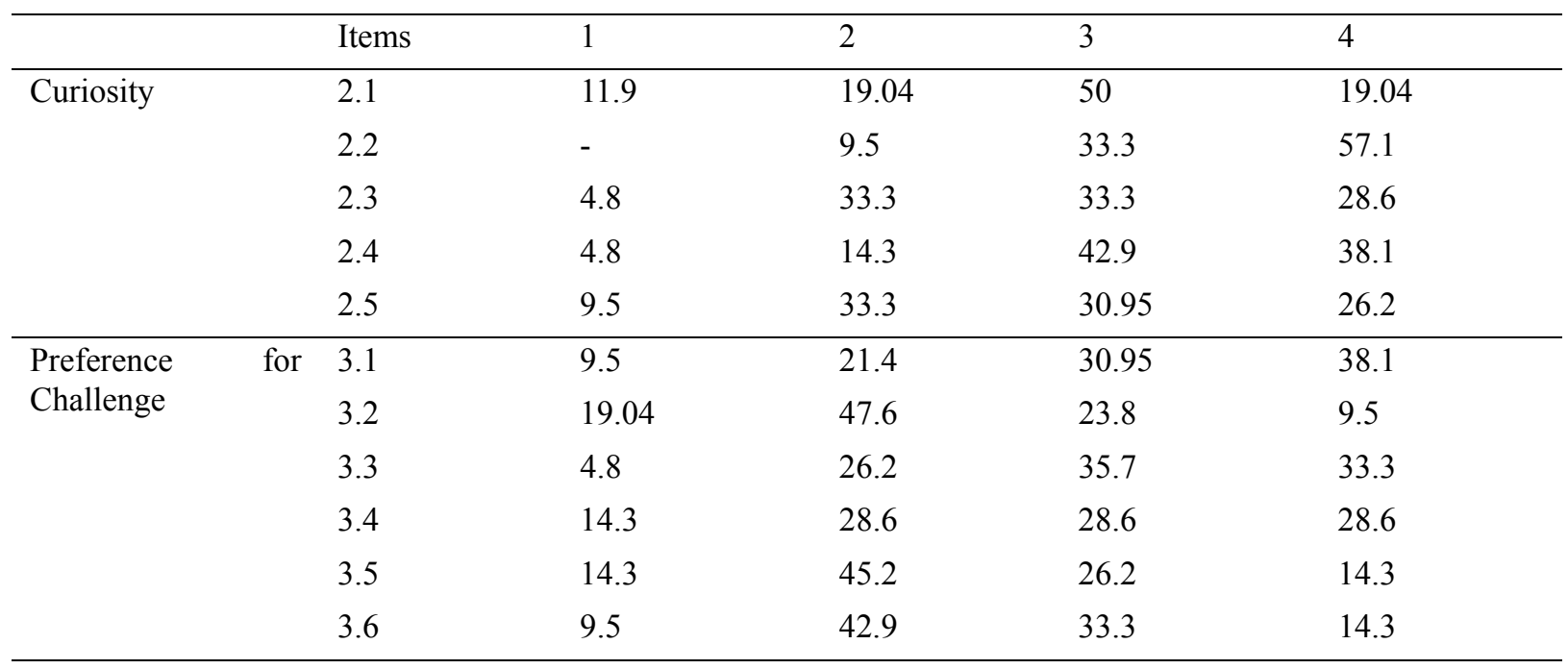

Based on Table 2 above, the largest percentage in curiosity factor showed in the item number 2.2. There were $57.1 \%$ in four-point Likert scale. The learners agree that reading such an interesting text can make them happy. Meanwhile, in preference for challenge construct, the largest percentage is reached by the first item. There were $38.1 \%$ learners motivated in reading L2 text when the text is difficult material. This percentage can be said as the smaller percentage compared with two previous factors which can reach $45.2 \%$ in involvement and $57.1 \%$ in the curiosity. 
Table 3. The result of questionnaire in extrinsic drive to excel: competition and recognition

\begin{tabular}{llllll}
\hline & Items & 1 & 2 & 3 & 4 \\
\hline Competition & 4.1 & - & 4.8 & 23.8 & 71.4 \\
& 4.2 & 7.1 & 14.3 & 21.4 & 57.1 \\
& 4.3 & 2.4 & 11.9 & 30.95 & 54.8 \\
& 4.4 & 16.7 & 28.6 & 33.3 & 21.4 \\
& 4.5 & - & 7.1 & 19.04 & 73.8 \\
& 4.6 & - & 23.8 & 28.6 & 47.6 \\
\hline Recognition & 5.1 & 14.3 & 57.1 & 19.04 & 9.5 \\
& 5.7 & - & 9.5 & 21.4 & 69.04 \\
& 5.2 & 4.8 & 11.9 & 28.6 & 54.8 \\
& 5.3 & 9.5 & 21.4 & 30.95 & 38.1 \\
& 5.4 & 7.1 & 16.7 & 30.95 & 45.2 \\
& 5.5 & 2.4 & 23.8 & 52.4 & 21.4 \\
& 5.6 & 2.4 & 23.8 & 45.2 & 28.6 \\
& 5.7 & - & 35.7 & 21.4 & 42.9 \\
& 5.8 & 2.4 & 16.7 & 30.95 & 50 \\
\hline
\end{tabular}

Table 3 presents the first extrinsic factor drive to excel which divided into competition and recognition. The first largest percentage showed by the statement number 4.5 . It gets $73.8 \%$ which indicated that the learners want to be the best at reading in English. Then the second greatest number is showed by number 4.1. There were 71.4\% learners who like to work harder so that they can read better than others in English. The second construct of the extrinsic drive to excel is recognition. It consists of eight statements. $69.04 \%$ of the learners agree with the statement number 5.1. This means that learners were happy when the teacher gives positive comments about their reading ability in English.

Table 4. The result of questionnaire in extrinsic academic compliance: compliance and grade

\begin{tabular}{llllll}
\hline & Items & 1 & 2 & 3 & 4 \\
\hline Compliance & 6.1 & 2.4 & 16.7 & 30.95 & 50 \\
& 6.2 & 4.8 & 30.95 & 28.6 & 35.7 \\
& 6.3 & - & 9.5 & 47.6 & 42.9 \\
& 6.4 & - & 4.8 & 19.04 & 76.2 \\
\hline Grade & 7.1 & - & 2.4 & 23.8 & 73.8 \\
& 7.2 & - & 23.8 & 35.7 & 38.1 \\
& 7.3 & - & 9.5 & 21.4 & 66.7 \\
& 7.4 & - & 16.7 & 26.2 & 57.1 \\
\hline
\end{tabular}

Table 4 presents the second extrinsic factor; extrinsic academic compliance. Both of compliance and grade consist of four statements. In the compliance, the largest percentage is gained by the item number 6.4 . It reaches $76.2 \%$ in the four-point Likert scale for the statement "I read in English in order to pass my English courses". This number is followed by the item number 6.1 in which a half of the learners agree with the statements saying that finishing English reading assignments on time is very important for them. It can be seen from the table in which $50 \%$ learners choose the four-point Likert scale. Then, in grade construct, there are $73.8 \%$ of the learners agree with the statement number 7.1. It means 31 students believe that it is important for them to get a good score in English reading course. Besides, the item number 7.3 also get the high percentage. $66.7 \%$ of the learners want to read in English in order to improve their grades. 
Table 5. The result of questionnaire in extrinsic test compliance and extrinsic social sharing

\begin{tabular}{|c|c|c|c|c|c|}
\hline & Items & 1 & 2 & 3 & 4 \\
\hline \multirow{4}{*}{$\begin{array}{ll}\text { Extrinsic } & \text { Test } \\
\text { Compliance } & \end{array}$} & 8.1 & 2.4 & 16.7 & 38.1 & 42.9 \\
\hline & 8.2 & 2.4 & 7.1 & 35.7 & 54.8 \\
\hline & 8.3 & 2.4 & 16.7 & 40.5 & 40.5 \\
\hline & 8.4 & - & 4.8 & 23.8 & 71.4 \\
\hline \multirow{4}{*}{$\begin{array}{ll}\text { Extrinsic } & \text { Social } \\
\text { Sharing } & \end{array}$} & 9.1 & 7.1 & 33.3 & 40.5 & 16.7 \\
\hline & 9.2 & 7.1 & 40.5 & 38.1 & 14.3 \\
\hline & 9.3 & 9.5 & 47.6 & 35.7 & 7.1 \\
\hline & 9.4 & 16.7 & 45.2 & 28.6 & 11.9 \\
\hline
\end{tabular}

Table 5 consists extrinsic test compliance and extrinsic social sharing. Those constructs have four items of each. According to the questionnaire's result above, the largest percentage in the extrinsic test compliance is showed by compliance item number 8.4. There were $71.4 \%$ of learners who practice reading in English because they need to do well in their future class. The other items which related to the standardized score test also get the high percentage in the four-point of Likert scale. Those are $42.9 \%, 54.8 \%$ and $40.5 \%$.The last factor is extrinsic social sharing. Based on Table 5, the largest percentage has reached by the item 9.3 in the two-point of Likert scale. It indicates the learners do not like talking with their friends about what they read in English. It also happens in the items number 9.2 and 9.4 in which it gets $40.5 \%$ and $45 \%$ of each in the Likert scale number 2 "a little different from me".

\section{Discussion}

The discussion is divided into two types of motivation; intrinsic and extrinsic motivation. The intrinsic motivation included the involvement, curiosity, and preference for the challenge. The extrinsic motivation involves the extrinsic drive to excel, extrinsic academic compliance, extrinsic test compliance, and extrinsic social sharing.

\subsection{Intrinsic Motivation}

Based on the questionnaire's result, it cannot be concluded that involvement factor in the item number 1.2 has high influence in intrinsic motivation but it is also concern on the result of the other items. In the items number 1.1 and 1.3, it shows that the learners are not familiar with English reading. The confirmation result from the interview found that they were the lack of knowledge and experience in English reading due to their educational background experiences in Senior High School. In the interview session also found that the learner (AN) stated: "I read an English text when I was in reading subject". He honestly said that it was his first time to read the English text. While the others admitted that they tend to choose reading material written in Indonesian instead of reading in English. Reading in English is such a hard thing to do for them, contrarily, reading material in Indonesian text was easier for them.

Based on the questionnaire's result, the learners' curiosity did not boost them to read the English text. It can be seen through the low percentages of the Likert scale number 4 that are shown in the items number $2.1 ; 2.3 ; 2.4$; and 2.5. On the other hand, curiosity's roles were in particular condition of the English reading. The learners have curiousness to read the topics in English related to their interest such as romance, mystic, history, and daily information. It can assume that the interesting topic of the learners played a role in motivating them to engage in English reading activity. In the interview, the learners were asked whether they want to read such a new article or not. A learner (HR) said, "It depends on the topic of the article". This statement implies that the learner wanted to read such certain topic only. It shows that the learners have their own personal topics of interest and will definitely choose to read an article related to it.

In accordance with the questionnaire's result, this construct did not seem to contribute many motivations for the learners to read the English text. There were 47.6\% learners from the item 3.2 and $45.2 \%$ learners from the item 3.5 admitted that they did not enjoy to read such a difficult English text. They also did not like to challenge themselves in English reading. It is due to their lack of vocabulary in English. This made them facing many difficulties in understanding the English text. Hence, they tended to read the text which is easier to be understood. Based on Koda (as cited in Grabe, 2009), reading in L2 is more complex than reading in L1. It is because reading in L2 needs both of L2 and L1 background knowledge. So, when the learners did not have enough background of knowledge in 
L2 language, it can cause difficulties for the learners' comprehension in reading L2 text. This actually can also be affected by the experiences of the learners in L2 reading. If the learners are frequently reading in L2, they definitely enrich their vocabulary (Cho \& Krashen, 1994). It can also help to develop their L2 background of knowledge. This argument clearly explains more the conclusion that the experience of the learners in English reading is really important. It will give them more experiences in English reading and enrich their vocabulary and English background of knowledge. As the result, the learners can be more motivated in English reading without being afraid to face many difficulties and they can be easier to get involved in English reading class.

\subsection{Extrinsic Motivation}

The extrinsic motivation in driving to excel consisted of competition and recognition. In competition, generally, the learners have a desire to be the best learners in reading the English text. This desire motivated them to increase their English reading activity. They were also willing to work hard to be better than their friends in English reading. This was shown by the items that get high percentages in Likert scale number 4 . Besides, through the interview result, it was also found that the learners tried to be the active students in the classroom.

In recognition, the learners like to get positive comments about their ability in reading the English text from their teacher and friends. It shows the percentages of the items number 5.1, 5.2, 5.4, and 5.7. The percentage of the first item obtained $69.04 \%$. It means the learners like to be rewarded by their teacher when they read well the English text. $54.8 \%$ also like to be rewarded as the good English readers. $42.9 \%$ of the learners are even happy when their friends acknowledge their ability in English reading. These facts indicated that the learners will be more motivated to read after they get the reward from their teacher and friends. In this case, the learners admitted that they were happy when the teacher gives compliments about their right answer for the question. They also felt happy for the compliments given by their teacher as the appreciations for their effort and courage in reading class activities. They stated that even they did many mistakes in pronouncing words in reading, their teacher still appreciated it. It actually can influence the learners' motivation whether they can enjoy the class or not.

In the interview session, the participants also were asked about the thing that can affect to enjoy the reading class. A learner (AZ) answered, "It depends on the teacher". In the interview, the learners said that a certain teacher can build such an atmosphere where they can enjoy the class without under pressure feelings. Therefore, in this construct, the English reading' teacher played an important role to motivate the students by creating such an atmosphere that makes them enjoy the reading class.

The next factor was extrinsic academic compliance; involving compliance and grade. Compliance contains four items. Compliance in this construct means the learners' willingness in reading the English text to complete their assignments. Based on the questionnaire, it shows that the learners motivated in reading caused by this factor. It is shown from the item number 6.4 in which there were $76.2 \%$ who tried to read the English text in order to pass their English courses. Besides, it is also shown by the item number 6.1 which a half of the learners considered that finishing English reading assignments were very important. It was supported by the interview session result. They admitted that finishing and submitting assignments lately will definitely influence their score. It can be concluded that the learners were motivated to read in English due to the importance of the assignments.

The second construct of the extrinsic academic compliance was grade. It described as a desire to receive a good grade in reading (Wang \& Guthrie as cited in McGeown, 2013). In this case, it shows that the learners were motivated in reading because of the willingness to get a high score. Through the item number 7.4 (57.1\%), it shows a half of the learners work harder on English assignments when they were graded. Based on the interview, they stated that they will try the best to do the reading assignments. They tried to finish and collected it on time in order to get a good score. In the item4, there were $73.8 \%$ of the learners who felt the important of a good grade in their English reading score, $66.7 \%$ of them wanted to read the English assignments to improve their grades, and $38.1 \%$ were looking forward to finding out their grades in English reading. Those results show that the grades motivated and influenced them to read the English text.

The third factor of extrinsic motivation was extrinsic test compliance which divided into the mixture of competition, recognition, and compliance items. Based on the questionnaire's result, it found that the item number 8.4 got the highest percentage in four-point of the Likert scale. $71.4 \%$ of the participants practice reading in English to read well in their future classes. The three items 8.1, 8.2, and 8.3 were related to each other dealing to the role of English reading in the standardized test like TOEFL, IELTS, etc. Though they admitted that many of them did not ever try to get the English standardized test yet but they agreed that reading the English text help them to increase their score on the standardized test. Some of the learners claimed that they were motivated to read more in English due to the reading materials in the standardized test.

The last factor was the extrinsic social sharing involved the satisfaction feeling attained through sharing about the 
meaning gained from reading with peers. The social sharing was also related to the learners' engagement in social interactions (Wang \& Guthrie, as cited in McGeown, 2013). In this factor, Komiyama limits the person whom the learners can share with. He is only focused on the sharing activity between the learners and their friend, rather than the teacher or other adults. Based on the questionnaire, the learners explained that they did not really enjoy to share what they read in English materials. The item number 9.1 reaches only $16.7 \%$, and the item number 9.2 get $14.3 \%$ for the Likert scale number 4 . The result of interview found that sharing was a kind of personal activity. They cannot easily share something to their friends randomly. They prefer to share what they read to whom they know well. This might happen because of the lack of intensity in reading the English text.

The $47.6 \%$ of Indonesian learners did not like to talk with their friends about what they read in English. Besides, 19 or about $45.2 \%$ participants did not like to join the class discussion related to what they read in English. This can be concluded that friends did not motivate them in reading activity. In the interview session found that some learners admitted that parents also become one of the partners they can share with. They could easily share it with their parents without the anxiety. Compared with the result of the social construct in Kusumaningputri's article (2014), it shows the different result that the learners usually share a particular topic related to the politic only.

In line with the earlier discussion, the people surrounds the learners, involving the teacher, friend, and family also played the roles to increase the learners' motivation in reading the English text. It suggested by Anderman and Anderman (as cited in Dornyei \& Ushioda, 2011), the teacher played the important role in motivating the student by giving frequently reading assignments and some compliments to the learners in appreciating their courage in English reading class' activities. The teacher also played a role in creating the class' atmosphere in which all the students can enjoy the reading class without feeling anxious or even under pressure.

\section{Conclusion}

In this part, the researchers concluded that the experiences of the EFL learners influence their intrinsic motivation in reading English texts. The learners who have more experiences in English reading have more desire to read the English texts. It will be easier for them to get involved to English texts than other who lack experiences. It is due to their knowledge in grammars and vocabularies than others who did not. This fact helps them much to understand English materials even such difficult English texts like journals which can challenge them. According to arguments above, it can be concluded that the learners who tend to read simple English texts can be said as the learners who were lacking English reading experiences.

The extrinsic motivation of recognition constructs played the roles in reading activity. The desire of the learners to compete and gain the highest score in reading class can move them to read more in English. Besides, they were also motivated to read in English because they want to be recognized by others such as teacher and friends. The second factor involves compliance and grade construct. The frequent assignments given by teacher contribute much in motivating the learners to read in English. It happens especially for the assignment which is graded. The learners are more motivated to give their best in English reading in order to improve their grades in reading class. The third is extrinsic test compliance factor. The importance of English standardized test makes the learners increasing their English reading activity. The last is extrinsic social sharing. In this construct, it is found that friends are not the only place where the learners can share withFamily also plays an important role in this activity.

Both intrinsic and extrinsic motivation played the roles in motivating the learners to read in English. Considering intrinsic motivation, the topics of English text should be those that were still interesting, because it can trigger the desire of the learners to read in English. For extrinsic motivation, the teacher has such an important role to motivate the learners in English reading especially in the classroom. The teacher can help to increase the motivation of the learners extrinsically by giving frequent assignments and creating a good atmosphere in English reading classroom where the learners can enjoy the reading class.

For further research, it is recommended to find the English reading motivation of the EFL learners by using different instruments. The other researcher also can observe reading motivation in relation to variables such as aptitudes, and learning strategies. This research expectedly can help further researchers in doing observations related to motivation of Indonesian EFL learners. Finally, the researchers hope this study can contribute to the other similar studies which deal with second language acquisition and learning.

\section{References}

Ahmadi, M. R. (2011). The Effect of Integrative and Instrumental Motivation on Iranian EFL Learners' Language Learning. ELT Voices India.

Barkoukis, V., Tsorbatzoudis, A., Grouios, G., \& Sideridis, G. (2008). The assessment of extrinsic and intrinsic motivation and amotivation: Validity and reliability of the Greek version of the Academic Motivation Scale. 
Assessment in Education: Principles, policy \& Practice, $15(1), \quad 39-55$. https://doi.org/10.1080/09695940701876128

Bin-Tahir, S. Z. (2012). Teaching English as World Language: Pengajaran Bahasa Inggris. Jakarta: Media Pustaka Qalam.

Bin Tahir, S. Z. (2015). Multilingual Education in Pesantren Context. Yogyakarta: Penerbit Deepublish.

Bin-Tahir, S. Z., \& Hanapi. (2017). Lecturers' Method in Teaching Speaking at the University of Iqra Buru. International Journal of English Linguistics, 7(2), 73-80. https://doi.org/10.5539/ijel.v7n2p73

Cho, K., \& Krashen, S. D. (1994). Acquisition of vocabulary from the Sweet Valley Kids series: Adult ESL acquisition. Journal of Reading, 37(8), 662-667.

Corbin, B. (2008). Unleashing the potential of the teenage brain: 10 powerful ideas. Thousand Oaks, CA: Corwin Press.

Deci, E. L., \& Ryan, R. M. (2000). Intrinsic Motivation and Extrinsic Motivation: Classic Definitions and New Directions. Contemporary Educational Psychology, 25, 54-67. https://doi.org/10.1006/ceps.1999.1020

Denscombe, M. (2007). The Good research guide: for small-scale social research projects (3rd ed). Philadelpia: Open University Press.

Dhanapala, K. V. (2008). Motivation and L2 Reading Behaviours of University Students in Japan and Sri Langka. Journal of International Development Cooperation, 14(1).

Dörnyei, Z. (2007). Research methods in applied linguistics: Quantitative, qualitative and mixed methodologies. Oxford: Oxford University Press.

Dörnyei, Z., \& Ushioda, E. (2011). Teaching and Researching Motivation (2nd ed). England: Longman.

Deporter, B., \& Hernacki, M. (1992). Quantum Learning: Membiasakan Belajar Nyaman dan Menyenangkan. Translated by Alwiyah Abdurrahman. Bandung: Kaifa PT Mizan Pustaka.

Grabe, W. (2009). Reading in a Second Language: Moving from Theory to Practice. Cambridge: Cambridge University Press.

Johnson, K., \& Morrow, K. (1987). Communication in the Classroom: Applications and Methods for a Communicative Approach. Great Britain: Longman.

Kirby, E., \& McDonald, J. (2009). Engage every student: motivation tools for teachers and parents. Minneapolis, MN: Search Institute Press.

Komiyama, R. (2013). Factors underlying second language reading motivation of adult EAP students. Reading in a Foreign Language, 25(2), 149-169.

Kusumaningputri, R. (2014). Indonesian Learner's Motivation in English Reading Classroom. Journal of English Language and Culture, 4(2), 134-149.

Masduqi, H. (2014). EFL Reading in Indonesian Universities: Perspectives and Challenges in Cultural Contexts. Journal of Teaching and Education, 3(03), 385-397.

Masuhara, H. (2003). “Material for Developing Reading Skill” in Tomlinson (Ed), Developing Material for Language Teaching. New York. Continuum.

Mao, Z. (2011). A Study on L2 Motivation and Applications in Reading Class in Senior High School. Theory and Practice in Language Studies, 1(12), 1731-1739. https://doi.org/10.4304/tpls.1.12.1731-1739

McGeown. S. P. (2013). Reading Motivation and Engangement In The Primary School Classroom: Theory, Research, and Practice. Leicester: UKLA.

Pang, E. S. (2003). Teaching Reading. International Bureau of Education. Retrieved on August 14th, 2012, from http://.scribd.com/ docs/24hzkyp20umdez4plla.pdf

Rivers, W. M. (1981). Teaching Foreign Language Skills. Chicago: The University Chicago Press.

Salikin, H., \& Bin Tahir, S. Z. (2017). The Social Media-Based Approach in Teaching Writing at Jember University, Indonesia. International Journal of English Linguistics, 7(2), 73-86. https://doi.org/10.5539/ijel.v7n3p46

Tomlinson, B. (Ed). (2003). Developing Material for Language Teaching. New York: Continuum.

Troike, M. S. (2006). Introducing Second language Acquisition. Cambridge: Cambridge University Press. 


\section{Copyrights}

Copyright for this article is retained by the author(s), with first publication rights granted to the journal.

This is an open-access article distributed under the terms and conditions of the Creative Commons Attribution license (http://creativecommons.org/licenses/by/4.0/). 